\title{
Cruise Vessels Air Pollution Inventory for the Port of Kotor
}

\section{Karlo Bratića , Ladislav Stazića , Miroslav Vukičevićb, Branko Lalića}

Prevention of air pollution from ships, according to MARPOL Annex VI, regulates the emission of specific pollutants contained in the exhaust gases into the atmosphere. In this paper, the Port of Kotor is analysed as a case study because of its distinct geographical features, permanent attraction for tourists, and the title of the third busiest port in the Adriatic in 2017. Ships arriving to the Port of Kotor represent one of the major sources of air pollution not only in the Port area, but also in Boka Kotorska Bay as an approach route towards the Port. For calculation of air pollution inventory in this case study, ship engines' power method was used. The focus of the research analysis is on the cruise ships visiting the Port of Kotor in 2018. For that reason, all ships under 500 GT were excluded from the analysis. The pollution shows clear seasonal pattern characteristic for ports in the Mediterranean. This behaviour is emphasised as an increasing problem that needs to be addressed. The seasonal pattern causes $82.6 \%$ of all air pollution from cruise vessels concentrated in the period from May to November.

\section{KEY WORDS}

$\sim$ Port of Kotor

$\sim$ Air pollution

$\sim$ Emission

$\sim$ Carbon dioxide

a. University of Split, Faculty of Maritime Studies, Split, Croatia

e-mail: kbratic@pfst.hr

b. University of Montenegro, Faculty of Maritime Studies, Kotor, Montenegro

e-mail:miroslav.v@ucg.ac.me

doi: 10.7225/toms.v10.n01.016

This work is licensed under (cc) BY

Received on: Mar 23, 2020 / Revised on: Sep 23, 2021 / Accepted on:Dec 9, 2021 / Published online: Feb 1, 2021

\section{INTRODUCTION}

Boka Kotorska Bay (Figure 1) is the largest bay in the Adriatic Sea; the name is derived from the town of Kotor situated at the bottom of the bay, $15.5 \mathrm{Nm}$ from the narrow bay entrance. This area is the "one of the most attractive cruising destinations in the Adriatic Sea" (Nikolić, Gagić and Ivošević, 2016), showing "not only great potential in terms of economy, but also great danger if environmental issues are taken into consideration" (Nikolić, Gagić and Ivošević, 2016). The Port of Kotor ranks as the 3rd busiest port in the Adriatic in 2017 and the 56th busiest port in the world (Cruise Activities in MedCruise Ports: Statistics, 2017). During that year, over 540,000 tourists visited the town from large cruise vessels. There were several studies of the impact of pollution caused by the amount of the traffic in the approaches to the Port of Kotor and in Boka Kotorska Bay (Dragovic, Tzannatos, Tselentis, Meštrović and Škurić, 2015) as well as studies how to optimise the overcrowding of the area (Škurić, Maraš, 2017; Kofjač, Škurić, Dragović and Škraba, 2013). A significant part of pollution coming from the traffic is air pollution ("a mix of particles and gases that can reach harmful concentrations") from the exhaust emissions of cruise vessels (National Geographic, 2019). The emissions are divided into greenhouse gases and pollutants.

Greenhouse gasses trap the heat in the Earth's atmosphere, hence their name. The main greenhouse gas in the atmosphere is carbon dioxide $\left(\mathrm{CO}_{2}\right)$. Today, a great part of $\mathrm{CO}_{2}$ is produced by burning of fossil fuels (Third IMO Greenhouse Gas Study, 2014). Pollutants from the exhaust emission of shipping industry are mainly nitrogen oxides (NOx), sulphur oxides (SOx), particulate matter (PM), volatile organic compounds (VOC). Pollutants may cause various harmful effects on human and animal health as well as acid rain; they form harmful ground level ozone decreasing vegetation growth. PM and VOC, among other effects, contribute to climate change (Clear Seas, 2019; Vukičević, Mraković and Ivošević, 2018). 
The Port of Kotor, as one of the Mediterranean Sea ports, is heavily affected by seasonal fluctuation of marine traffic. Impact of maritime transport emissions on coastal air quality in the area also follows the same pattern (Viana et al., 2014) as can be seen in Figures 2, 3 and 4.

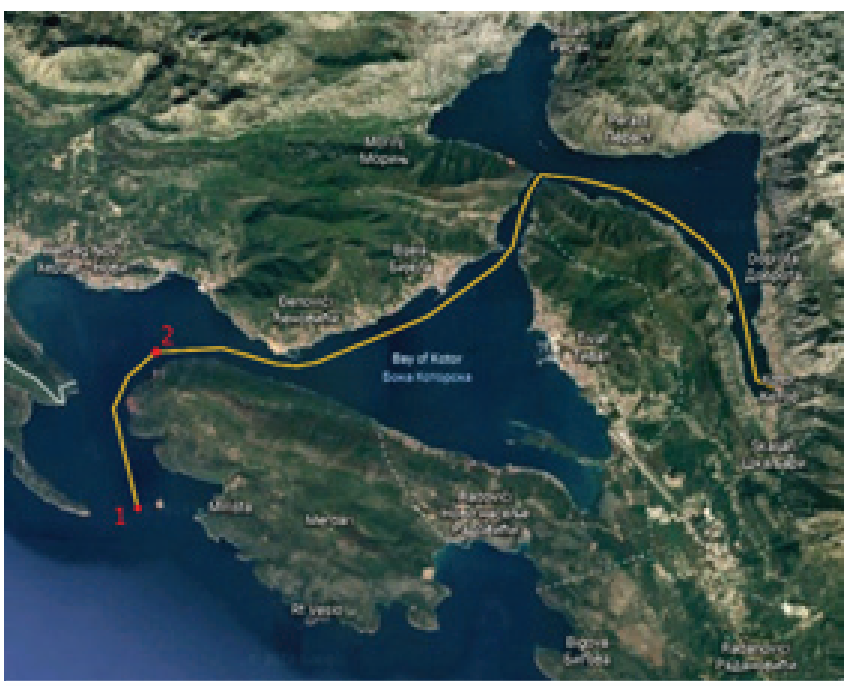

Figure 1.

Boka Kotorska Bay (Google Earth, 2019).

\section{THE METHODOLOGY}

Air pollution from marine traffic is regulated by the resolution adopted in 1997 by the Marine Environmental Protection Committee (MEPC) of the International Maritime Organization (IMO) (EU research, Transport related Air Pollution and Health impacts, 2014). The emissions are addressed in Annex VI of the Marine Pollution Convention (MARPOL).

There are various approaches to defining marine traffic airpollution emissions. In this paper, ship's power method (Trozzi, 2010) is used to create an inventory of exhaust gas emissions. This method is recommended by EMEP/EEA (European Environment Agency, 2016) and features a simple implementation that requires relatively few parameters for calculations. The parameters required for calculation of air pollution emissions using this method are:

- $\quad$ Ship movement (distance and duration),

- $\quad$ Propulsion type, type of fuel, propulsion engine power and auxiliary engine power,

- Ship's stay in port.

The emission (E) of a ship during a visit (Google Earth, 2019) to Boka Kotorska Bay is (Trozzi, 2010):
$E_{\text {trip }}=E_{\text {maneuvering }}+E_{\text {hotelling }}$

Manoeuvring and hoteling emissions are calculated according to equations:

$$
\begin{aligned}
& \left.E_{\text {maneuvering }}=\frac{D}{V} \cdot\left[\left(M E \cdot L F_{M E} \cdot E F\right)+\left(A E \cdot L F_{A E}\right) \cdot E F\right)\right] \\
& E_{\text {hotelling }}=T \cdot\left[A E \cdot L F_{A E} \cdot E F\right]
\end{aligned}
$$

where:

D - Distance travelled [m],

$\mathrm{V}$ - Average ship speed $[\mathrm{m} / \mathrm{s}]$,

ME - Main engine power [kW],

$\mathrm{LF}_{\mathrm{ME}}$ - Main engine load factor [\%],

$\mathrm{AE}$ - Auxiliary engine power [kW],

$\mathrm{LF}_{\mathrm{AE}}$ - Auxiliary engine load factor [\%],

$\mathrm{EF}$ - Emission factor, depending on the type of fuel and the engine speed $[\mathrm{g} / \mathrm{kWh}]$,

$\mathrm{T}$ - Average time spent at berth or manoeuvring per call [h].

According to this method, if manoeuvring time is unknown, it can be determined as a proportion of the distance travelled and the average speed of the ship. In addition, air polluting emissions from oil-fired boilers are not taken into account. Although the authors considered including emissions from boilers into account, such parameter was not compliant with the method used, and information regarding work hours and fuel consumption of oil-fired boilers is usually not available or, at best, difficult to obtain.

The Kotor Port Authority kindly provided the authors with accurate and up-to-date information about the number of vessels and their time spent in port. In conjunction with available on-line information about the shipping traffic and basic information about each particular ship, an emission inventory was created.

\subsection{Ship Speed and Manoeuvring Distance}

Ship movement (manoeuvring) towards the Port of Kotor is distance travelled between the pilot boarding point and the docking point (berth). Pilot can board a vessel (Port of Kotor, 2019):

- In fair weather, in position $42^{\circ} 23^{\prime} \mathrm{N}$ and $18^{\circ} 33.4^{\prime} \mathrm{E}(15.1 \mathrm{Nm}$ - pos. 1 in Figure 1).

- In bad weather, in position $42^{\circ} 26.4^{\prime} \mathrm{N}$ and $18^{\circ} 32.8^{\prime} \mathrm{E}(13.8$ $\mathrm{Nm}$ - pos. 2 in Figure 1). 
The research showed that the pilot commonly boarded the vessel in the fair-weather position; therefore, manoeuvring distance of 13.8 nautical miles will be taken as relevant.

International Regulations for Preventing Collisions at Sea state: "Every ship shall at all times proceed at a safe speed so that she can take proper and effective action to avoid collision and be stopped within a distance appropriate to the prevailing circumstances and conditions" (International Regulations for Preventing Collisions at Sea, 2019). Manoeuvring speed is limited for Boka Kotorska Bay to 10 knots. The speed in Kumbor and the Verige Strait is further reduced to 6 knots (Government of Montenegro, 2013). The total manoeuvring time for the Port of Kotor is about 2 hours, with mooring/unmooring included (Port of Kotor, 2019).

\subsection{Cruise Ships in Boka Kotorska Bay}

Generally, vessels arriving to the Port of Kotor significantly vary in size. To avoid numerous smaller vessels, such as small passenger vessels and smaller yachts, a limit has been set for this research to 500 GT. This limit allows comparison with similar inventories of air pollution in the Adriatic Sea (Knežević, Radonja, Dundović, 2018; Milošević-Pujo and Jurjević, 2004). During 2018, 375 cruise ship with different propulsion engines arrived in Boka Kotorska Bay, as presented in Table 1. Auxiliary engines are medium-speed engines in all the vessels considered.

\subsection{Fuel and Emissions}

Shipping industry commonly uses lower-quality fuels, which results in the contribution on the global scale of pollution
Table 1.

Cruise vessel propulsion details.

\begin{tabular}{lll} 
Propulsion type & Number of arrivals & Percentage \\
\hline Medium-speed engine & 122 & $32.5 \%$ \\
\hline Slow-speed engine & 17 & $4.5 \%$ \\
\hline $\begin{array}{l}\text { Diesel-electric, } \\
\text { medium-speed }\end{array}$ & 236 & $63 \%$ \\
\hline
\end{tabular}

of $15 \%$ from NOx, $13 \%$ from SOx, while greenhouse gasses emissions contribute by only $2.2 \%$ (Clear Seas, 2019). According to the EU regulations (EURLex, 2016) and their local application (Law on Air Protection, 2010), ships coming to the Bay can use fuels with high sulphur content for approach and manoeuvring, but they must change to fuel with low sulphur content (less than $0.1 \%$ ) immediately after berthing (Rule-book on the quality and quality control of liquid oil fuels, 2016). From the pre-arrival checklist provided by two cruising ship companies (anonymous by their request), it is visible that the owners recommend change to low-sulphur fuel during preparations for manoeuvring to avoid possible problems with the local authorities and the following fines. Those checklists are applicable for all EU ports as well as ports in Montenegro, Albania and Turkey, where those ships regularly call.

The calculation presented in the paper follows on-board practice found in the checklist (Ships use MDO/MGO low-sulphur fuels, with less than $0.1 \%$ of sulphur by mass). Fuel property with the appropriate emission factor (EF) for a specific air pollutant is shown in Table 2.

Table 2.

Low-sulphur fuel (<0.1\%) marine diesel engine pollution emission (EURLex, 2016), (Browning and Bailey, 2006).

\begin{tabular}{lllll} 
Engine & $\mathrm{EF} \mathrm{CO}_{2}(\mathrm{~g} / \mathrm{kWh})$ & $\mathrm{EF} \mathrm{SO}_{2}(\mathrm{~g} / \mathrm{kWh})$ & $\mathrm{EF} \mathrm{PM}(\mathrm{g} / \mathrm{kWh})$ & $\mathrm{EF} \mathrm{VOC}(\mathrm{g} / \mathrm{kWh})$ \\
\hline Slow-speed & 588 & 0.37 & 0.4 & 0.6 \\
\hline Medium-speed & 652 & 0.41 & 0.4 & 0.5 \\
\hline
\end{tabular}

\subsection{Load Factors and Aux Power}

The main engine load factor is calculated according to the Equation 4 (Browning and Bailey, 2006):

$L F=\left(\frac{A S}{M S}\right)^{3}$ where:

$$
\begin{aligned}
& \mathrm{LF}=\text { load factor }(\text { in percent) } \\
& \mathrm{AS}=\text { actual speed }(\text { knots) } \\
& \mathrm{MS}=\text { maximum speed (knots) }
\end{aligned}
$$

Auxiliary engine load factor is calculated according to Table 3 (Browning and Bailey, 2006), (Trozzi, 2010), (Stazić et al. 2020): 
Table 3.

Auxiliary engine load.

\begin{tabular}{lll} 
Ship-Type & Manoeuvring & Hoteling \\
\hline Bulk Carrier & 0.45 & 0.22 \\
\hline Container & 0.50 & 0.17 \\
\hline Cruise & 0.80 & 0.64 \\
\hline General Cargo & 0.45 & 0.22 \\
\hline Tanker & 0.45 & 0.67
\end{tabular}

Where the data about auxiliary engines was not available, the ratio given in Table 4 (Browning and Bailey, 2006), (Trozzi, 2010), (Stazić et al. 2020) was used for calculation.

Table 4.

Auxiliary to Propulsion ratio.

\begin{tabular}{ll} 
Type of ship & Auxiliary to Propulsion Ratio \\
\hline Bulk Carrier & 0.222 \\
\hline Container & 0.220 \\
\hline Cruise & 0.278 \\
\hline General Cargo & 0.191 \\
\hline Tanker & 0.211
\end{tabular}

\subsection{NOx Regulation Applicability and Emission}

Three different levels of the maximum emission factors for NOx $(\mathrm{g} / \mathrm{kWh})$ are in use for marine diesel engines (Browning and Bailey, 2006). The values for each tier are taken from the EU research, Transport-Related Air Pollution and Health Impacts (International Maritime Organization, RESOLUTION MEPC.176 (58), 2008). The number of vessels per tier is given in Table 5.

\section{Table 5.}

Ships in the Port of Kotor according to NOx regulation applicability.

\begin{tabular}{rll} 
& Number & Percentage (\%) \\
\hline $\begin{array}{l}\text { No Tier requirement } \\
\text { applicable }\end{array}$ & 51 & 13.6 \\
\hline Tier 1 requirement applies & 279 & 74.4 \\
\hline Tier 2 requirement applies & 45 & 12 \\
\hline Total & $\mathbf{3 7 5}$ & \\
\hline &
\end{tabular}

NOx emission factors ( $\mathrm{g} / \mathrm{kWh}$ ) are based on the fuel used (MGO/MDO) and are taken only for manoeuvring and hoteling. NOx emission factors are presented in Table 6 (Trozzi, 2010).

\section{Table 6.}

NOx emission factors for manoeuvring and hoteling.

\begin{tabular}{llll} 
Engine & Type & $\begin{array}{l}\text { NOx (2000) } \\
(\mathrm{g} / \mathrm{kWh})\end{array}$ & $\begin{array}{l}\text { NOx EF (2005) } \\
(\mathrm{g} / \mathrm{kWh})\end{array}$ \\
\hline Main & Medium-speed diesel & 13.2 & 12.8 \\
\hline Main & Slow-speed diesel & 17.0 & 16.4 \\
\hline Auxiliary & Medium-speed diesel & 13.9 & 13.5 \\
\hline
\end{tabular}

\section{CALCULATION OF EMISSIONS AND RESULTS}

Air pollution emission is calculated using Equations 2 and 3, using the data from Chapter 2 regarding distances and manoeuvring speed. The emission is calculated for 2018 and presented in Table 7.
As shown in Table 7, a total of 375 ships that arrived to the Port of Kotor during 2018 emitted 68,360.5 tons of $\mathrm{CO}_{2}$, mostly during the summer and early autumn, as shown in Figure 2. 
Table 7.

Emissions of cruise ships arriving in the Port of Kotor for 2018.

\begin{tabular}{|c|c|c|c|c|c|c|c|c|c|c|c|c|c|}
\hline Month & Jan & Feb & Mar & Apr & May & Jun & Jul & Aug & Sep & Oct & Nov & Dec & Total \\
\hline $\begin{array}{l}\text { No of } \\
\text { Vessels }\end{array}$ & 4 & 5 & 11 & 13 & 43 & 48 & 52 & 57 & 49 & 55 & 26 & 12 & 375 \\
\hline $\begin{array}{l}\text { Engine } \\
\text { [kW] }^{*}\end{array}$ & 10,032 & 1,642 & 13,074 & 23,166 & 21,147 & 20,112 & 21,719 & 19,841 & 22,178 & 25,518 & 25,220 & 16,891 & $21,272 *$ \\
\hline $\begin{array}{l}\mathrm{CO}_{2} \\
\text { [ton] }\end{array}$ & 344.7 & 72.3 & $1,234.4$ & $2,889.8$ & $7,829.2$ & $7,929.0$ & $9,675.5$ & $9,694.9$ & $93,10.5$ & $12,023.4$ & $56,18.7$ & $17,38.1$ & $68,360.5$ \\
\hline $\begin{array}{l}\text { SOx } \\
\text { [ton] }\end{array}$ & 0.3 & 0.1 & 1.3 & 3.3 & 7.9 & 9.2 & 8.6 & 8.3 & 7.9 & 10.7 & 4.9 & 1.5 & 63.9 \\
\hline $\begin{array}{l}\text { PM } \\
\text { [ton] }\end{array}$ & 0.3 & 0.1 & 1.2 & 3.2 & 7.7 & 9.0 & 8.3 & 8.1 & 7.7 & 10.4 & 4.8 & 1.5 & 62.4 \\
\hline $\begin{array}{l}\text { VOC } \\
\text { [ton] }\end{array}$ & 0.3 & 0.1 & 1.5 & 4.1 & 9.6 & 11.3 & 10.4 & 10.1 & 9.6 & 13.0 & 6.0 & 1.8 & 78.0 \\
\hline $\begin{array}{l}\text { NOx } \\
\text { [ton] }\end{array}$ & 6.2 & 2.3 & 27.9 & 75.5 & 191.5 & 220.7 & 206.5 & 202.6 & 190.1 & 263.2 & 125.1 & 34.8 & $1,546.3$ \\
\hline \multicolumn{14}{|c|}{ *Average propulsion engine size } \\
\hline ** Differ & nces in $t$ & e total & re possib & ane to & unding $c$ & the num & bers to on & e decimal & & & & & \\
\hline
\end{tabular}

\section{$\mathrm{CO}_{2}$ [ton]}

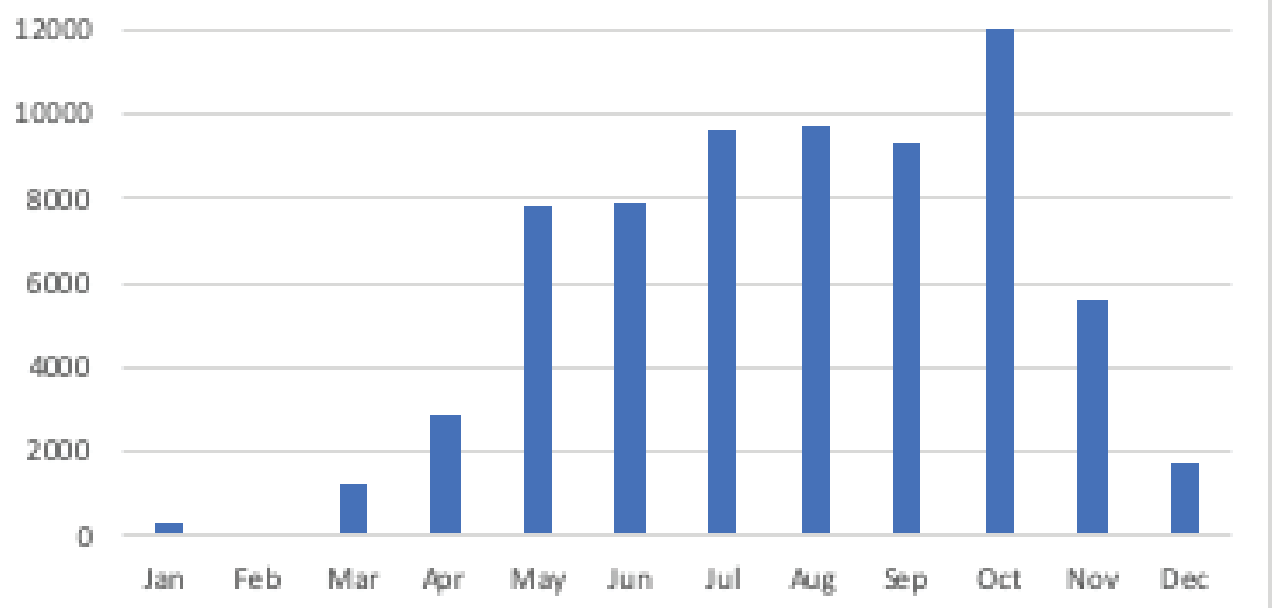

Figure 2.

Distribution of $\mathrm{CO}_{2}$ emissions in 2018.

Vessels emitted 63.9 tons of SOx, 62.4 tons of PM, 78.0 tons of VOC and 1,546.3 tons of NOx. In Figure 3, distribution of emissions of SOx, PM and VOC is presented, and it shows the same pattern as the $\mathrm{CO}_{2}$ emission pattern. Distribution of NOx also follows the pattern, which is visible in Figure 4. 


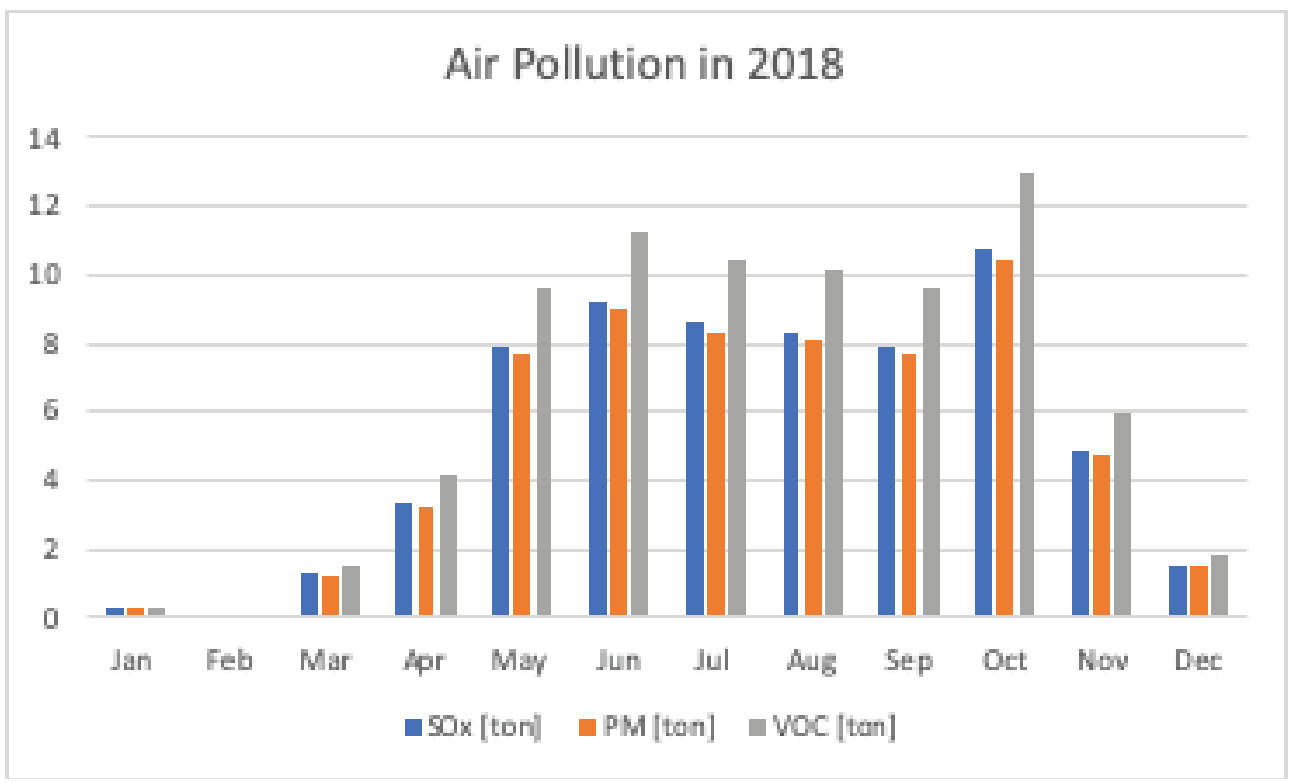

Figure 3.

Distribution of SOx, PM and VOC emissions during 2018.

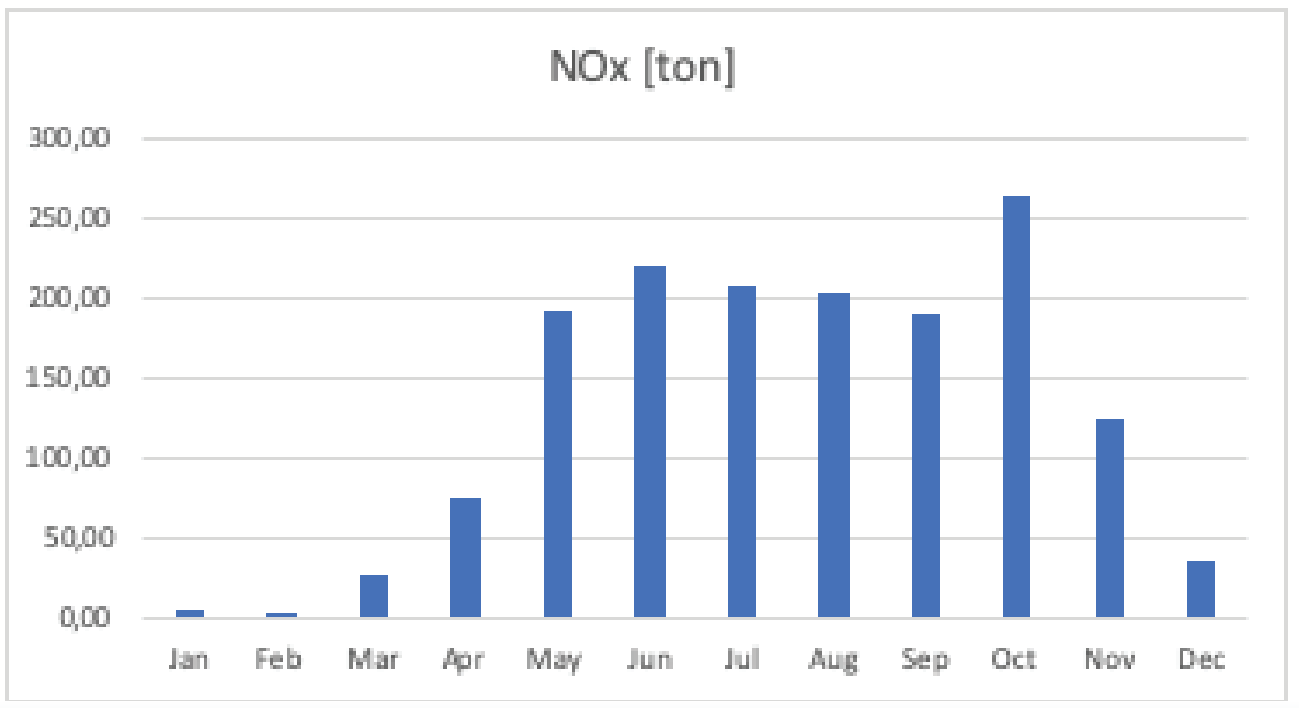

Figure 4.

Distribution of NOx emissions in 2018.

Figures 3 and 4 show that most of the emissions are released from May to October, which follows the pattern described by Viana et al. (Viana et al., 2014). This paper was written before the traffic data for 2019 was collected and analysed.

Now, the only available data is the total number of vessels in 2019, which shows the growing trend of $11.7 \%$ (419 cruise vessels in 2019 in the Port of Kotor). There is announcement of continuation of such a trend; the Port of Kotor expected the arrival of 540 cruise ships in 2020. As the number of cruise ships in Montenegro has been growing in recent years, it is vital to control the harmful emissions from ships, which can be done using calculations presented in this paper, application of simulation software or on-site expensive measurements (Vukičević, Gagić and Nikolić, 2017; Vukičević, 2016). 


\section{CONCLUSION}

This research has estimated the emissions inventory from cruise vessels arriving to the Port of Kotor, one of the busiest cruise destinations on the East Adriatic Coast. Ships arriving to the Port of Kotor are one of the major sources of air pollution not only of the Port area, but also Boka Kotorska Bay as an approach route towards the Port. In 2018, there were 375 visits of cruise vessels larger than 500 GT. Calculation of air pollutant emissions was performed after collecting the vessels' data (the power of the engines, type of fuel, load factor, time of manoeuvring and stay in port...). According to the calculation, those vessels emitted $68,360.5$ tons of $\mathrm{CO}_{2}, 63.9$ tons of SOx, 62.4 tons of PM, 78.0 tons of VOC and 1,546.3 tons of NOx. The pollution shows a clear seasonal pattern characteristic for ports in the Mediterranean, which emphasises the problem. The seasonal pattern is the cause of $82.6 \%$ of all air pollution from cruise vessels concentrated in the period from May to November.

The Port of Kotor cruise-vessel arrival list for 2019 and the announced arrival list for 2020 confirm a steady growth of the cruise vessel arrivals to the Port. This is followed by an increase in the pollution emissions and a decline of the quality of life in the surrounding area.

There is a precise instruction about ship speed in Boka Kotorska Bay, whereby the effects of the ship speed on the environment are not taken into account. Modelling of ship speed and load may pave the way for creating changes in air pollution emissions. An analysis of that scenario should be the next step in a study on how to reduce the pollution in the area.

\section{REFERENCES}

Browning, L., Bailey, K., 2006. Current Methodologies and Best Practices for Preparing Port Emission Inventories, ICF Consulting, Aptos, CA. Available at: https:// www3.epa.gov/ttnchie1/conference/ei15/session1/browning.pdf, accessed on 11 September 2019.

Clear Seas, 2019. Available at: https://clearseas.org/en/air-pollution/, accessed on: 08 September 2019.

COLREGS - International Regulations for Preventing Collisions at Sea, 2019. Available at: https://www.jag.navy.mil/distrib/instructions/COLREG-1972.pdf , accessed on: 27 February 2019.

Dragović, B. et al., 2018. Ship emissions and their externalities in cruise ports. Transportation Research Part D: Transport and Environment, 61, pp.289-300. Available at:

http://dx.doi.org/10.1016/j.trd.2015.11.007.

EU research, Transport related Air Pollution and Health impacts - Integrated Methodologies for Assessing Particulate Matter, Collaborative Project, (20102014), Large-scale Integrating Project, SEVENTH FRAMEWORK PROGRAMME, ENV.2009.1.2.2.1, Transport related air pollution and health impacts.
EURLex, DIRECTIVE (EU) 2016/802 OF THE EUROPEAN PARLIAMENT AND OF THE COUNCIL of 11 May 2016 relating to a reduction in the sulphur content of certain liquid fuels, Available at: https://eur-lex.europa.eu/legal-content/HR/TXT/PDF/?uri= CELEX:32016L0802\&from=EN, accessed on: 15 November 2019.

European Environment Agency, EMEP/EEA air pollutant emission inventory guidebook 2016; Technical guidance to prepare national emission inventories, Denmark. Available at:

http://dx.doi.org/10.2800/247535.

Google Earth, 2019. Available at: https://www.google.com/earth/, accessed on: 08 September 2019.

Government of Montenegro, 2013. Law on the Safety of Maritime Navigation of Montenegro, Chapter 10, pp. 5/70.

International Maritime Organization, RESOLUTION MEPC.176(58). Available at: http://www.imo.org/en/KnowledgeCentre/IndexofIMOResolutions/MarineEnvironment-Protection-Committee-(MEPC)/Documents/MEPC.176(58).pdf, accessed on: 16 September 2019

International Maritime Organization, Third IMO Greenhouse Gas Study 2014, Available at: http://www.imo.org/en/OurWork/Environment/PollutionPrevention/ AirPollution/Documents/Third \%20Greenhouse \%20Gas \%20Study/GHG3 \%20 Executive \%20Summary \%20and \%20Report.pdf, accessed on: 03 September 2019.

Knežević, V., Radonja, R. \& Dundović, Č., 2018. Emission Inventory of Marine Traffic for the Port of Zadar. Pomorstvo, 32(2), pp.239-244. Available at: http://dx.doi.org/10.31217/p.32.2.9.

Koffač, D. et al., 2013. Traffic Modelling and Performance Evaluation in the Kotor Cruise Port. Strojniški vestnik - Journal of Mechanical Engineering, 9(59), pp.526535. Available at:

http://dx.doi.org/10.5545/sv-jme.2012.942.

Law on Air Protection, 2010. Official Gazette of Montenegro, No. 025/10 of 5 May 2010.

Medcruise, Cruise Activities in MedCruise Ports: Statistics 2017. Available at: http:// www.medcruise.com/sites/default/files/2018-03/cruise activities in medcruise ports-statistics_2017_final_0.pdf, accessed on: 01 September 2019.

Milošević-Pujo, B., Jurjević, N., 2004. Onečišćenje mora iz zraka emisijom ispušnih plinova, Naše more, 51(5-6), pp. 178-184. Available at: https://hrcak.srce.hr/8435, accessed on: 15 November 2019.

National Geographic, 2019. Available at: https://www.nationalgeographic.com/ environment/global-warming/pollution/, accessed on: 08 September 2019.

Nikolić, D., Gagić, R. \& Ivošević, Š., 2016. Estimation of Air Pollution from Ships in the Boka Kotorska Bay. The Boka Kotorska Bay Environment, pp.117-128. Available at: http://dx.doi.org/10.1007/698_2016_34.

Port of Kotor, 2019. Available at: http://www.portofkotor.co.me/O-luci/pilotazaplovila.html, accessed on: 28 October 2019.

Rule book on the quality and quality control of liquid oil fuels, 2016. Official Gazette of Montenegro, No. 1/2016.

Škurić, M., Maraš, V., 2017. Some results of nautical risk assessment in port, Proc. 7th International Maritime Science Conference, Solin, Croatia, April 20-21, 2017, Solin, Croatia, pp. 335-339. Available at: https://bib.irb.hr/datoteka/931109.imsc2017 book of proceedings final.pdf\#page $=345$. 
Stazić, L. et al., 2020. The Port of Split international marine traffic emissions inventory. Pomorstvo, 34(1), pp.32-39. Available at: http://dx.doi.org/10.31217/p.34.1.4.

Trozzi, C., 2010. Emission estimate methodology for maritime navigation, 9th International Emissions Inventory Conference, San Antonio, Texas September 27 30, 2010. Available at: https://www3.epa.gov/ttnchie1/conference/ei19/session10/ trozzi.pdf, accessed on: 22 March 2019.

Viana, M., et al., 2014. Impact of maritime transport emissions on coastal air quality in Europe, Atmospheric Environment 90, pp. 96-105. Available at: https://doi.org/10.1016/j.atmosenv.2014.03.046.
Vukičević M., 2016. Mogućnost upotrebe simulacionih softvera u cilju predikcije emisije oksida azota (NOx) iz brodskog motora MAN B\&W, MSc thesis, University of Montenegro, Faculty of Maritime Studies in Kotor.

Vukičević M., Gagić R., Nikolić D., 2017. Application of simulation software in estimation of NOx emissions from ship's main engine at different loads, Proc. 7th International Maritime Science Conference, Solin, Croatia, April 20-21, 2017, Solin, Croatia, pp. 531-543. Available at: https://bib.irb.hr/datoteka/931109.imsc2017 book of proceedings final.pdf.

Vukičević M., Mraković I., Ivošević Š., 2018. Analysis of the influence of preventive maintenance of main engines on working parameters and emissions, 5. konferencija “Održavanje 2018" Zenica, 10-12 May 2018, pp. 247 - 254. 